\title{
Treating primary-progressive multiple sclerosis: potential of ocrelizumab and review of B-cell therapies
}

This article was published in the following Dove Press journal:

Degenerative Neurological and Neuromuscular Disease

I February 2017

Number of times this article has been viewed

\author{
Jenny J Feng' \\ Daniel Ontaneda ${ }^{2}$ \\ 'Department of Neurology, \\ ${ }^{2}$ Mellen Center for Multiple Sclerosis, \\ Cleveland Clinic, Cleveland, $\mathrm{OH}$, USA
}

Correspondence: Daniel Ontaneda Mellen Center for Multiple Sclerosis, Cleveland Clinic, 9500 Euclid Ave, UIO Mellen Center, Cleveland, OH 44195, USA

Tel +l $216218284 \mid$

Email ontaned@ccf.org
Abstract: Multiple sclerosis (MS) therapy has evolved rapidly with an increased availability of several immunomodulating therapies over the past two decades. Disease-modifying therapies have proven to be effective in treating relapse-remitting MS (RRMS). However, clinical trials involving some of the same agents for secondary-progressive and primary-progressive MS (SPMS and PPMS) have been largely negative. The pathogenesis of progressive MS remains unclear, but B-cells may play a significant role in chronic compartmentalized inflammation, likely contributing to disease progression. Biologics targeted at B-cells, such as rituximab, are effective in treating RRMS. Ocrelizumab is a humanized monoclonal antibody to CD $20^{+} \mathrm{B}$-cells that has shown positive results in PPMS with a significant reduction in disease progression. This review aims to discuss in detail the involvement of B-cells in MS pathogenesis, current progress of currently available and investigational biologics, with focus on ocrelizumab, and future prospects for B-cell therapy in PPMS.

Keywords: Ocrelizumab, primary progressive multiple sclerosis, B-cells

\section{Development of multiple sclerosis medications over time}

Multiple sclerosis (MS) has been described in the medical literature as early as in the 14th century; however, it was only formally characterized by Charcot in 1867 as le sclerose en plaque based on autopsy findings of characteristic plaques in brain parenchyma. Charcot subsequently made unsuccessful attempts to treat MS with strychnine, gold, and silver treatment. ${ }^{1}$ In the mid-20th century, corticosteroids were found to be effective in improving relapse symptoms, but without any effects on relapse rate reduction or disease progression. It was not until the early 1990s that the first true disease-modifying therapies (DMT) for MS were approved. IFN $\beta$ was found to be effective in reducing enhancing lesions and relapse rate, as well reducing risk of sustained Kurtzke Expanded Disability Status Scale (EDSS) progression..$^{2-4}$ IFN $\beta-1 b$ also showed success in secondary-progressive MS (SPMS) by slowing disease progression in a European study in $1998 .{ }^{4}$ This was the first foray into investigating agents for progressive form of MS, with the end goal of delaying time to confirmed disability progression (CDP). Although in the follow-up North American study of more advancedstage SPMS patients, IFN $\beta-1 b$ did not demonstrate the same effects in reducing CDP as was seen in the European study, the North American study did show that IFN $\beta-1 b$ reduced relapses, gadolinium-enhancing lesions (GELs), and radiographic disease 
burden in SPMS..$^{5}$ In that same decade, glatiramer acetate (GA) was found to have protective effects on new lesion formation and relapses. ${ }^{6,7}$ However, in a 2007 trial, GA failed to show significant delay in disease progression compared to patients who received placebo in primary-progressive MS (PPMS) patients. ${ }^{8}$

Mitoxantrone, a type II topoisomerase inhibitor, was shown to reduce EDSS progression in SPMS patients when compared to placebo in $2000 .{ }^{9}$ However, its use was limited by potential for cardiotoxicity. Natalizumab, a selective molecule that prevents central nervous system (CNS) migration of lymphocytes via blocking lymphocytic integrin attachment to endothelial surface receptors, was shown in placebocontrolled trials to have robust effects against relapses and inflammatory disease. ${ }^{10,11}$ In patients already on IFN $\beta$-1a therapy, the addition of natalizumab further reduced probability of progression, annualized relapse rate (ARR), and new or enlarging T2 lesion. ${ }^{12}$ A recent large study of secondary progressive MS (ASCEND) using natalizumab however showed negative results. ${ }^{13}$

Fingolimod, a sphingosine-1-phosphate receptor modulator, showed improved ARR, radiographic disease burden, and disease progression in relapsing-remitting multiple sclerosis (RRMS), ${ }^{14,15}$ but was negative in a large randomized trial in PPMS. ${ }^{16}$ Teriflunomide, a dihydro-orotate dehydrogenase inhibitor, became the second oral agent that was approved for RRMS in 2012 after Phase III trials showed its efficacy in reducing $A R R$, delaying disability progression, and improving MRI outcomes. ${ }^{17}$ Dimethyl fumarate, a derivative of fumaric acid, the mechanism of which in MS is still unknown, became the third approved oral agent for RRMS in 2013 after multiple Phase III trials showing favorable results and good tolerability. ${ }^{18,19}$

After natalizumab, another monoclonal antibody, rituximab, which targets CD20 antigens that are primarily on B-cells, also gained momentum in MS after Phase I and II trials showing efficacy in RRMS. ${ }^{20,21}$ A Phase II/III trial in PPMS rituximab was not as encouraging, giving mixed results in different subgroups. ${ }^{22}$ However, this led to the advancement of a whole spectrum of cell-specific monoclonal antibodies used in MS therapy. Alemtuzumab, which targets CD52 antigen expressed on B- and T-cells, was approved by United States Food and Drug Administration (FDA) to treat RRMS in 2014 after it showed marked reduction in both relapses and disability progression measures. ${ }^{23,24}$ Daclizumab, another humanized monoclonal antibody designed to target CD25 on T-cells, was approved by FDA for the treatment of RRMS in 2016. Ocrelizumab, the focus of this paper, is a monoclonal antibody designed to target $\mathrm{CD} 20^{+}$expressed on premature B-cells. It is currently undergoing FDA fast-track evaluation for PPMS. It is the first of the MS DMTs to have shown beneficial results in a purely progressive MS population. Ofatumumab is a similar antibody that also targets $\mathrm{CD} 20^{+}$and is currently being evaluated for its efficacy in both RRMS and PPMS.

As illustrated in the preceding paragraphs, since the days when MS was treated with gold, silver and strychnine, current options for treatment have evolved drastically. RRMS is now a treatable disease with a plethora of disease-specific agents, each with its own efficacies, route of administration, and side effect profile, all of which should be taken into account in tailoring treatment regimen and individualizing therapy. As for PMS, however, there is still a paucity of medications. Currently approved DMTs for RRMS have not proven effective in PMS trials. The failure of these DMTs in PMS may be in part due to the fact that they target T-cells, which were traditionally thought to be the main contributor in MS disease pathology. Research in understanding MS pathogenesis over the past few decades have shown that B-cells also play important roles in activating autoimmunity as well as regulating and amplifying proinflammatory response. The differential role of the B-cell in progressive forms of MS remains an open and interesting question. The importance of B-cell functions has been demonstrated in multiple trials involving B-cell-depleting therapies in RRMS and, more recently, in PMS. The promising results in reducing disease progression in PMS have been encouraging and will be now discussed in detail.

\section{B-cell mediated pathophysiology of MS}

MS lesions, which characterize the disease, occur in both brain parenchyma as well as the cortex. In white matter, MS lesions typically undergo three stages of temporal evolution. Acute lesions are characterized by blurred margins of demyelination and axon damage and increased parenchymal edema. They also contain prominent perivascular infiltration of inflammatory cells that are predominantly myelin-reactive T-cells, and some plasma cells and macrophages. In contrast, chronic lesions demonstrate sharp margins and increased scar tissue. Chronic active lesions are comprised of hypocellular and gliotic cores surrounded by borders of active inflammation similar to those observed in acute lesions. In contrast, chronic silent lesions are devoid of inflammation and are instead characterized by loss of oligodendrocytes, demyelinated axons, and hyalinzed vessel walls. ${ }^{25}$ Cortical 
lesions are more commonly seen in progressive type of MS. ${ }^{26}$ These include lesions that are confluent with subcortical white matter lesions, perivascular lesions, and subpial lesions. Compared to white matter lesions, gray matter lesions contain fewer inflammatory components such as T-cells or macrophages. ${ }^{27}$ However, there is a significant correlation between cortical demyelination and diffuse meningeal, perivascular, and parenchymal inflammation. ${ }^{26}$ In light of the discovery of meningeal B-cell follicles in SPMS and related CNS lymphatic structures (discussed later in this review), ${ }^{28-30} \mathrm{~B}$-cells are suggested to play a more significant role in disease progression beyond the acute inflammatory stage than we have previously recognized.

\section{Role of B-cells}

B-cells are crucial in multiple steps along the dysfunctional immune pathway in MS. B-cells drive the humoral immunity process and differentiate into antigen-presenting cells that engage in costimulatory relationship with T-cells. During CNS inflammation, B-cells are attracted into the CNS from the peripheral lymphoid system via chemical signaling. Then they mature inside the CNS, secrete antibodies, participate in both pro-/anti-inflammatory processes, and modulate T-cell function in acute and chronic inflammation. ${ }^{31}$

Traditionally, MS has been regarded as a classic T-cellmediated process via the proinflammatory actions of regulatory T-cells, T-helper (Th) 1, Th2, and Th17 cells. However, recent investigations have found B-cells as equally crucial players in MS pathophysiology. B-cells have been found to form ectopic lymphoid follicles at sites of active inflammation in multiple disease conditions. Likewise, in MS patients, B-cells are rampant throughout the CNS - they have been found in meninges, brain parenchyma, and in cerebrospinal fluid (CSF). ${ }^{28,29,32,33}$ A major function of B-cells is in humoral immunity in which B-cells differentiate into antigen-presenting cells that engage in a costimulatory relationship with T-cells and secrete antibodies. Similar to T-cells, B-cells become activated in the periphery via antigen binding. Various autoantigens have been speculated in MS that are distinct from known autoantigens in other autoimmune diseases. ${ }^{34}$ Once bound to an antigen, B-cells presentation to T-cells is conducted via T-cell receptor and major histocompatibility complex coupling. While there are many different antigen-presenting cells, B-cells provide specialized antigen recognition and maintain a reciprocal activation relationship with T-cells. Once antigen presentation occurs, B-cells are then induced to become antibodyproducing plasma cells and migrate into CNS via chemokine signaling. The intrathecal production of antibodies by B-cells is confirmed by the presence of oligoclonal bands (OCB) in CSF. While important in diagnosis, the roles of oligoclonal bands in human disease mechanisms remain to be further investigated. Numerous antibodies have been found in MS plaques on histopathological studies. In studies of animal models of experimental autoimmune encephalitis (EAE) and histopathological studies of human MS lesional tissue, myelin-specific antibodies such as MOG, MBP, and PLP were found to be deposited on myelin sheaths, ${ }^{35,36}$ thereby facilitating the demyelination process via antibody-antigen recognition. In some MS patients, there is also a set of antibodies that bind to antigen targets on astrocytes and neuronal tissues rather than directly to myelin; ${ }^{37,38}$ some were found to contribute to gray matter lesions. ${ }^{39}$ The multitude of antibodies detected in various MS pathologies suggests that B-cell-mediated CNS attack is complex and contributes to the heterogeneity of MS immunopathologies. Antibodies may be disease specific and require further characterization to better modulate immunotherapy.

Besides antibody production, B-cells also produce various cytokines such as IL-6, TNF- $\alpha$, and LT- $\alpha$. In MS patients, there is an increased number of IL-6-producing B-cells subtypes. ${ }^{32}$ IL-6 assists in development of not only Th17 cells but also further upregulates B-cell pathogenesis. LT- $\alpha$ and TNF- $\alpha$ stimulate inflammatory process, and LT- $\alpha$ helps form secondary lymphoid structures. In addition to proinflammatory cytokine production, B-cells also secret IL-10, an anti-inflammatory cytokine that has been found to regulate the extent of disease progression by suppressing T-cells and facilitate recovery from acute inflammation. ${ }^{31}$ In mice models of EAE, those that are deficient in regulatory B-cells that secrete IL-10 demonstrated failure to recover from EAE. ${ }^{40,41}$ It has also been demonstrated that autologous infusion of regulatory B-cells reduced disease severity in EAE. ${ }^{42}$

\section{OCB presence}

OCB presence in CSF is indicative of intrathecal B-cell activity, which has been found to account for up to $25 \%$ of CNSinfiltrating lymphocytes. ${ }^{43}$ OCBs are mainly comprised of IgG isotypes, but sometimes can also contain IgM isotypes. OCB detection is a common diagnostic test used in CSF analysis of MS patients. Although not very specific, as OCB can be positive in various $\mathrm{CNS}$ inflammatory, infectious, or paraneoplastic conditions, it is a highly sensitive tool in MS diagnosis as it is positive in $88 \%-95 \%$ of patients with confirmed MS and $69 \%$ of patients with clinically isolated syndrome (CIS). ${ }^{44,45}$ More specifically, in confirmed MS patients, OCB containing 
predominantly IgG with kappa light chain pattern is more common, whereas in non-MS patients with OCB positivity, kappa and lamba light chains can be found in equivalent proportions. ${ }^{46,47}$ OCB positivity can also be used to risk stratify patients. Clinically isolated syndrome and radiographically isolated syndrome (RIS) patients with positive OCB are at increased odds of conversion into MS. In established MS patients with OCB positivity, there are increased odds of worsening disability, ${ }^{45,48}$ there is also increased likelihood for developing neutralizing antibodies to IFN $\beta .{ }^{49}$ The number of OCB also appears to correlate with disease severity in a retrospective analysis of patients with varying degrees of MS, with the more severe group who were OCB positive having a higher mean and median number of OCB (6 and 7 bands, respectively) compared to that of the benign group ( 3 and 5 bands, respectively). ${ }^{50}$ Furthermore, MS patients with IgMpositive OCBs have a worse prognosis ${ }^{51,52}$ and are more likely to relapse after interferon therapy. ${ }^{53}$ This suggests that OCB status and number in MS correlates with the degree of B-cell activity in MS, thus it is likely that different immunopathological subtypes of MS can respond differently to immunotherapy.

Traditionally, OCB were considered a terminal response to inflammation - the end product of terminally differentiated intrathecal antigen-producing plasma cells. While it is true that majority of OCB production in MS occur inside CNS, recent works have suggested that there may also be a component of peripheral activation that contributes to intrathecal B-cell activity. There was evidence in mass spectrometry analysis of OCB in MS patients that peripheral production of OCB can exist in parallel to that of CNS and that there is an ongoing dynamic exchange of B-cells across the blood-brain barrier during active disease that further enhances circulation of pathological B-cell response. ${ }^{54}$

The pathological significance of OCB remains to be further investigated. In studies of MS patients who undergo B-cell depletion therapies with rituximab or ocrelizumab that target CD20, there is a persistent presence of $\operatorname{IgG}$ and IgM concentrations across time despite rapid reduction of B-cell counts. ${ }^{21,55-57}$ However, in MS patients treated with natalizumab, there was a reduction in CNS immunoglobulin synthesis and OCB. ${ }^{58,59}$ This demonstrates that the effect of therapies (that either directly or indirectly affect B-cells) on B-cell activity in MS is complex and nonlinear.

\section{Follicle formation}

Follicle-like structures are areas where B-cells congregate, trafficked to target organs by chemokines and lymphotoxins such as BAFF, APRIL, and CXCL13 produced by various classes of lymphocytes. Within this local microenvironment, B-cells interact with T-cells and follicular dendritic cells, and they are stimulated to differentiate into antibody-secreting cells, and they proliferate within the follicular germinal center. These follicles can develop ectopically in target organs in the setting of chronic inflammation, such as in synovium of patients with chronic arthritis and rheumatoid arthritis (RA), ${ }^{60,61}$ in salivary glands in Sjogren's syndrome, ${ }^{62}$ and intraportally in patients with hepatitis $\mathrm{C} .{ }^{63}$ Similarly, in patients with MS, local follicular-like structures have also been found in the CNS. In postmortem analysis of brains and spinal cords of MS patients, follicle-like structures populated by B-cells along with T-cells and plasma cells have been found in the intrameningeal space, closely associated with perivascular inflammation..$^{29}$ The presence of CNS follicles has been hypothesized as a driver for graduated disability progression, especially in progressive MS where acute clinical or radiographic new lesions are relatively absent. ${ }^{64}$ It is thought that chronically activated immune clusters within meninges may contribute to the pathophysiology of progressive MS in which this reservoir of local inflammatory factors led to chronic demyelination, axonal degeneration, and subsequent axonal loss and may be associated with presence of subpial lesions characterized by gray matter demyelination and increased microglial activation. ${ }^{65}$ Although these so-called CNS follicles have not been found in all MS patients, some groups have described the presence of CNS follicles to be associated with the severity of cortical demyelination and neurodegeneration. ${ }^{28}$

In vivo, leptomeningeal enhancement on MRI has been detected in a portion of MS patients, with higher prevalence in progressive MS than in RRMS. Leptomeningeal enhancement is associated with subpial cortical demyelination, cortical volume loss, and clinical disability progression. ${ }^{65-68}$ When correlated with postmortem pathological analysis, leptomeningeal enhancement can be utilized as a possible MRI marker of follicle presence.

\section{GM-CSF-producing B-cells}

Granulocyte-macrophage colony-stimulating factor (GM$\mathrm{CSF}$ )-producing $\mathrm{B}$ cells are proinflammatory cells that express high levels of costimulatory molecules in addition to TNF- $\alpha$ and IL- 6 . This colony of cells is found in increased numbers in patients with MS and acts as a key contributor in the proinflammatory state. GM-CSF-producing B-cells induce myeloid cell activation. In vitro, they also enhance production of IL-12, IL-6, and IL-1B by macrophages. This also has been demonstrated in vivo where rituximab-treated 
B-cell-depleted RRMS patients demonstrate reduced macrophage production of IL-12 and IL-6 when compared to pretreatment levels. ${ }^{69}$

\section{Cytotoxic activity}

Antibody-dependent cell-mediated cytotoxicity (ADCC) and complement-dependent cytotoxicity (CDC) are important immune mechanisms in cellular defense. In MS patients, there is an increase in ADCC activity in peripheral lymphocytes when compared to age- and sex-matched controls. ${ }^{70}$ ADCC against myelin basic protein is increased in MS patients. ${ }^{71}$ Current B-cell depleting therapies utilize ADCC and $\mathrm{CDC}$ to target various B-cell subtypes. ADCC is an IgG mediated process - when IgG attaches to a surface receptor on its target cell, its Fc region can bind to Fc receptors on natural killer cells or macrophages. Such binding leads to target cell lysis or phagocytosis. CDC is also mediated via IgG attachment to target cells - a process that elicits complement-activating cascade that leads to eventual lysis of the target. These are the mechanisms of biologics used in MS - rituximab, ofatumumab and alemtuzumab - all of which are human or humanized monoclonal IgGs that bind to CD20 receptors with different binding affinities and intensity of cytotoxic activity induction. ${ }^{72}$

The various monoclonal antibodies that target CD20 have different binding affinities and degree of ACDD and CDC activity elicited. Mechanistically, they are divided into two types - type I and type II. Type I antibodies, which are also currently the most common type, induce translocation of the CD20 protein into lipid rafts and elicit subsequent cytotoxic activity. Type II antibodies, in comparison, lead to cell death by inducing homotypic adhesion rather than ADCC or CDC. ${ }^{73}$ The anti-CD20 antibodies mentioned in this paper, rituximab, ocrelizuab, ofatumumab, and ublituximab, are all type I antibodies. While all bind to the outer membrane portion of the CD20 transmembrane tetramer, they differ in target epitopes on the large and small loops of the antigen. Rituximab primarily binds to the ${ }^{170}$ ANPS ${ }^{173}$ motif, which is the end portion of the large amino acid loop, and binding to ${ }^{182}$ YCYSI $^{186}$ contributes complex stability. ${ }^{74-76}$ Ocrelizumab also binds to the same ${ }^{170} \mathrm{ANPS}^{173}$ core motif as rituximab; however, small differences in its complementary-determining regions (CDR) in complex with CD20 affect its binding affinity. ${ }^{75,77}$ Ofatumumab binds to a different portion on the large loop (FLKMESLNFIRAHTP), as well as regions in the small loop, resulting in increased affinity and potency compared to rituximab. ${ }^{75}$ Ublituximab binds to unique epitopes on the large loop as well and, in addition, is engineered to exhibit stronger affinity to Fc $\gamma$ RIIIa receptors, resulting in improved ADCC activity. ${ }^{78,79}$

\section{Rituximab and its utility in MS}

Rituximab is a chimeric monoclonal antibody that targets the CD20 antigen expressed on both pre-B and mature B-cells. It is a type I anti-CD20 antibody, which indicates that once rituximab is bound to its target epitope on the CD20 transmembrane protein via its Fab domain, the Fc domain induces translocation of CD20 into lipid rafts, which in turn activates ADCC and $\mathrm{CDC}$ mechanisms, leading to B-cell death. ${ }^{80}$ While rituximab's primary actions are on B-cells, it has also been shown to affect a minority of T-cells that are $\mathrm{CD} 20^{+}$. Mechanisms proposed suggest that T-cell depletion can occur as the end result of inhibiting B-cell-mediated antigen presentation and reduction of proinflammatory cytokines, there is also direct interaction of rituximab with $\mathrm{CD} 20^{+}$ T-cells leading to cytotoxic killing. ${ }^{81}$ From immunogenicity data from multiple clinical trials, rituximab has been shown to deplete both peripheral and CNS B- and T-cells in MS patients. $^{22,55,56,82}$

Rituximab was initially FDA-approved for the treatment of chemotherapy-resistant B-cell non-Hodgkin's lymphoma in 1997. Since then, it has also been approved as combination with chemotherapy to treat many other B-cell type lymphomas including follicular, diffuse large, low-grade, chronic lymphocytic leukemia (CLL), and in combination with methotrexate it is used to treat TNF-therapy-resistant rheumatoid arthritis. Rituximab's off-label use spans a wide spectrum of autoimmune diseases, including systemic lupus erythematous, Sjogren's syndrome, antineutrophil cytoplasmic antibody-induced vasculitis, and idiopathic thrombocytopenic purpura. In neurology, rituximab has been used to treat autoimmune/paraneoplastic conditions such as autoimmune encephalitis, ${ }^{83}$ opsonus-myoclonus syndrome, ${ }^{84}$ myasthenia gravis ${ }^{85}$ neuromyelitis optica (NMO) and neuromyelitis optica spectrum disorders, ${ }^{86,87}$ and MS. ${ }^{88}$

The safety and efficacy of rituximab was evaluated in patients with relapsing-remitting multiple sclerosis in an open-label Phase I study conducted in 2008 by Bar-Or et al. ${ }^{21}$ Twenty six RRMS subjects with at least 1 recent relapse and EDSS score of $\leq 5.0$ received 4 rituximab infusions (starting dose of $50-100 \mathrm{mg} / \mathrm{h}$ increased to maximum of $400 \mathrm{mg} / \mathrm{h}$ ) at weeks $0,2,24$ and 26 . They were followed for up to 72 weeks to assess safety. Rituximab was well tolerated. A majority of the patients $(77 \%)$ reported mild to moderate adverse events (AE) after the first infusion, including headache, chills, and hypotension. The proportion of AEs 
decreased with subsequent infusions. Mild to moderate infectious events such as upper respiratory infection (URI) or urinary tract infection (UTI) were also reported in $61 \%$ of the patients, a majority of whom had lower than normal IgM values compared to baseline. By week 2, complete peripheral B-cell depletion was achieved and remained depleted through week 48. B-cell depletion was associated with reduction in clinical relapses, new enhancing lesions, and radiographic burden of disease compared to the baseline period during the length of the trial.

Hauser et $\mathrm{al}^{56}$ performed a Phase II study in RRMS patients comparing effects of rituximab to placebo. In this study, 104 patients with RRMS with recent relapses within preceding year and EDSS score of $\leq 5.0$ were enrolled, 69 of whom were assigned to receive $1,000 \mathrm{mg}$ of rituximab infusion on days 1 and 15 while the other 35 received placebo. The patients who received rituximab showed $91 \%$ decrease in number of GELs during the 48-week trial. There was also a significant reduction in relapses at 24 weeks in patients who received rituximab compared to placebo. Peripheral $\mathrm{CD} 19^{+}$ B-cells were reduced by $95 \%$ and maintained until 24 weeks when $\mathrm{CD} 19^{+}$cells began to repopulate.

Rituximab has also been studied as an add-on therapy in 30 RRMS patients who have breakthrough relapses despite being on DMTs. After 4 weekly doses of $375 \mathrm{mg} / \mathrm{m}^{2}$ rituximab, there was a significant $88 \%$ reduction in GELs as well as improved multiple sclerosis functional composite (MSFC) scores compared to pretreatment baseline. EDSS scores remained stable. ${ }^{20}$

The effect of rituximab in progressive MS was investigated in the OLYMPUS trial ${ }^{22}$ - a multicenter, randomized, double-blind, placebo-controlled Phase II/III trial comparing rituximab to placebo in patients with PPMS. About 439 patients received 4 doses of $1,000 \mathrm{mg}$ of rituximab infused every 24 weeks with 96 week follow-up. Rituximab did not show efficacy in delaying disease progression or brain atrophy at the end of the 96-week study period; however, the group receiving rituximab did show reduced T2 volume progression and lower 25-foot walk scores compared to placebo. In further subgroup analysis, rituximab appeared to be more effective in delaying disease progression in a younger (less than 51 years old) cohort who had active GELs at baseline. The safety profile of rituximab was similar to that of the Phase I trial in RRMS in which there were similar, mild infusionrelated AEs; severe adverse reactions (4 pneumonia, 2 UTI, 2 cellulitis) were reported in $8.6 \%$ of the patient group that received rituximab. ${ }^{22}$ A recent large registry of over 800 subjects treated with rituximab in Sweden demonstrated excellent control of disease activity with relative stability of EDSS measures in RRMS patients; however, it failed to show efficacy in SPMS and PPMS patients. ${ }^{89}$ Tolerability and safety were similar to what has been described with prior observational studies. This same group conducted a comparative observational study of fingolimod and rituximab in 256 RRMS subjects and showed improved outcomes in those treated with rituximab..$^{90}$

Based on results from the aforementioned trials, it can be concluded that rituximab treatment in RRMS can reduce clinical relapses and GELs. However, in terms of delaying clinical disability progression, which is the goal of treating progressive form of MS, the effect is less obvious. In the RRMS group studied by Naismith et al, ${ }^{20}$ there were MSFC improvements over baseline that were mainly attributed to improvements in Paced Auditory Serial Addition Test, but the EDSS score was stable in 21/30 patients, improved in $7 / 30$ patients, and worsened in $2 / 30$ patients. Whether certain subcomponents of EDSS improved compared to others is unknown. In PPMS, based on OLYMPUS trial's subgroup analysis, rituximab appears to be most effective in younger PPMS patients who have more active inflammatory activity at baseline; however, the specific mechanism of action in this subgroup of patients remains unknown.

\section{Rituximab safety}

Since rituximab targets primarily B-cells, it has been proposed that it significantly affects monoclonal antibody production. Immunogenicity data from Phase I RRMS trial showed that IgM levels were selectively decreased after two doses of rituximab, while IgG and IgA levels remained the same in approximately half of patients. ${ }^{21}$ This was similarly reported in PPMS patients whose IgM levels remained below normal in approximately $1 / 3$ of patients who received rituximab. ${ }^{22}$ However in other studies, immunogenicity data have demonstrated only milder levels of association between study drug and immunoglobulin levels. In RRMS patients who received only a single dose of rituximab, only $22.4 \%$ had below-normal IgM levels but the median levels of $\operatorname{IgM}, \mathrm{IgG}$, and IgA were not significantly different from normal. ${ }^{56}$ Another study evaluating CSF changes after rituximab therapy found that B-cells were significantly depleted; however, OCB and IgG index were not affected despite B-cell depletion. ${ }^{82}$ This interesting observation is perhaps explained by the fact that plasma cells, which are the destination cells for antibody production, have downregulated CD20 membrane expression and thus are less affected by rituximab. ${ }^{91}$ 
Based on results from these aforementioned trials of rituximab in MS patients, it can be concluded that rituximab is generally safe to use, with most common reported AEs being minor infusion-related reactions (IRR) and mild infectious events. There were 3 deaths in the PPMS trial, however, only 1 out of the 3 patients received rituximab, and death was not directly related to rituximab but was rather due to aspiration pneumonia in the setting of existing brainstem lesions. The long-term side effects of rituximab infusion in MS patients remain to be elucidated, as none of the current published studies have followed the patients long term.

There is also the concern for progressive multifocal leukoencephalopathy (PML) given the degree of immunomodulation. PML is a near-fatal diffuse CNS demyelinating disease caused by reactivation of John Cunningham virus (JCV) in the CNS. It is most commonly seen in HIV infected patients whose immune surveillance mechanisms are impaired, leading to opportunistic infections. Likewise, in MS patients who are on immunomodulating therapies, most notably natalizumab, there is an increased risk for PML. Other MS DMTs including fingolimod, dimethyl fumarate, and rituximab have been associated with cases of PML. ${ }^{92,93}$ Mechanisms for JCV reactivation in this particular patient population remain to be further investigated. One hypothesis holds that latent JCV presence in the CNS with decreased immune surveillance in the setting of pathogenic strains of JCV results in PML. Another hypothesis postulates that latent JCV is harbored in pre-B cells and CD34+ cells. In the case of natalizumab, CD34+ cells harboring JVC are mobilized from bone marrow to peripheral blood due to blockage of adhesion molecules that attach these cells to the marrow matrix. In the case of rituximab induced B-cell depletion, JCV-harboring precursor cells clonally expand and repopulate in the periphery. In both cases, JCV viremia can occur causing PML. There are no reported cases of PML in MS patients treated with rituximab. But in clinical data from RA patients who were treated with rituximab, there is an estimated 1 case per 25,000 individuals with risk of developing PML. ${ }^{94}$ Although in this particular group of patients, it is hard to characterize the true risk since the 4 reported cases of RA patients who developed PML all had other PML risk factors such as chronic lymphopenia and history of prior prolonged use of immunomodulating and immunosuppresive therapies.

Long-term AEs related to rituximab infusion are perhaps better characterized in cohorts of NMO patients for whom rituximab is a commonly used treatment option. NMO is an autoimmune CNS disease that primarily involves spinal cord and optic nerves. Similar to MS, pathological examination of NMO lesions also shows B-cell involvement in terms of autoantibodies and IgG deposition. In an initial open-label study of 8 patients with NMO who received weekly rituximab treatment over the 4-week study period, there was a significant reduction in attack rate as well as improvements in neurological function. It was also well tolerated with minimal infusion related AEs. ${ }^{95}$ Since this initial study, rituximab has been established as an effective treatment for NMO. It has been shown to be safe when administered first as induction therapy followed by routine maintenance therapy over prolonged treatment courses and is effective in reducing relapse rates and improving or stabilizing disability. ${ }^{96-98}$ A larger retrospective study of 100 NMO patients who received maintenance rituximab infusions over median of 67 months showed similar results in relapse reduction rate and disability improvement. AEs included initial IRR that decreased over course of therapy and a few mild-moderate infection events including upper respiratory infections and herpes zoster that were determined to be unrelated to low IgG or IgM levels. There were 2 patients who became pregnant in between rituximab doses and delivered healthy babies. The most severe AE was 1 case of an elderly patient who died of pneumonia and septic shock after 6 years of treatment with rituximab and had concomitantly received 1 year of corticosteroid treatment for psoriasis. There were no reported cases of PML in this cohort. ${ }^{99}$

\section{Ocrelizumab and its current progress}

Ocrelizumab is a novel humanized recombinant monoclonal anti-CD20 antibody that targets the population of CD20 $0^{+}$cells including B-cell precursors and mature B-cells. ${ }^{100} \mathrm{~B}$-cells that differentiate into plasma cells lose $\mathrm{CD} 20^{+}$expression and thus are less targeted. ${ }^{91,101}$ Compared to rituximab's mechanism of action, ocrelizumab binds to a different but overlapping epitope of CD20. It exhibits greater biding affinity to $\mathrm{Fc} \gamma$ receptor IIIa (FcyRIIIa). ${ }^{102}$ Ocrelizumab depletes B-cells via ADCC as well as $\mathrm{CDC}$. In vitro experiments have shown that ocrelizumab exhibits greater ADCC activity and decreased CDC activity compared to rituximab, and in clinical trials it has demonstrated a more favorable antigenic profile when compared to rituximab and has reduced infusion-related toxicity. There is an immediate decrease in absolute peripheral and lymphoid tissue B-cell count after ocrelizumab infusion. ${ }^{103}$ There is also a significant proportion of $\operatorname{IgM}$ level reduction after ocrelizumab infusion. With regard to B-cell count recovery, there is a dose-dependent relationship - higher doses of ocrelizumab delay count recovery when compared to lower 
doses, and with higher doses, patients also maintain lower B-cell absolute count at 72-weeks follow up. ${ }^{104-107}$

Ocrelizumab was first investigated in an MS clinical trials involving RRMS subjects. In 2011, a Phase II, multicenter, randomized, parallel, double-blind, placebo-controlled trial enrolled 220 RRMS patients ages 18-55 years with baseline EDSS that ranged from 1 to 6 who had documented relapses 3 years preceding enrollment. SPMS and PPMS patients were excluded from the trial. Enrolled RRMS patients were randomly assigned to receive low-dose ocrelizumab (600 mg) or high-dose ocrelizumab $(2,000 \mathrm{mg})$ given via 2 cycles of IV infusion 2 weeks apart over 24 weeks, placebo, or IFN $\beta$-1a (30ug) IM injection weekly. All placebo and subjects in IFN arm received ocrelizumab infusions in the second cycle. The primary endpoint was total number of GELs throughout the 24-week treatment course. Results from this study showed that ocrelizumab reduced number of total and new GELs compared to placebo or IFN $\beta$-1a. It also reduced ARR, maintained low clinical disease activity, and slowed T2 lesion burden progression. Patients in the placebo and IFN groups who received ocrelizumab in the second cycle of treatment also achieved similar disease reduction results after switching. Low dose and high dose of ocrelizumab achieved similar outcomes except that the low-dose group achieved even lower mean ARR (13\%) compared to the high dose group (17\%), which was statistically significant against placebo or IFN $\beta$-1a. Near complete $\mathrm{CD} 19^{+} \mathrm{B}$-cell reduction was achieved after first cycle of infusion, and the low count was sustained at the end of the 24-week study. In terms of AEs, both ocrelizumab groups experienced more IRR compared to placebo; however, infection rates were similar between both ocrelizumab doses and placebo. ${ }^{57}$

\section{Phase III study in RRMS}

Following encouraging results from the Phase II study, a Phase III program (OPERA I and II) involving two identical multicenter, randomized, double-blind, double dummy, parallel-group trials were conducted to assess the safety and efficacy of ocrelizumab compared with IFN $\beta$-1a in RRMS patients. Eight hundred and twenty one and 835 RRMS patients of similar demographics and disease status (18-55 years old, baseline EDSS of $0.5-5.5$, and $>1-2$ clinical relapse 1-2 years preceding enrollment respectively) were randomized to receive ocrelizumab $600 \mathrm{mg}$ IV infusion every 24 weeks versus IFN $\beta$-1a 44 ug subcutaneously three times a week. Patients were followed throughout the 96-week treatment course with a primary endpoint of ARR at 2 years. Ocrelizumab showed significant reduction in ARR (46\% and
$47 \%$ for OPERA I and II, respectively), in addition, ocrelizumab also significantly reduced disability progression, total number of GELs, and total number of new T2 lesions. ${ }^{108} \mathrm{At}$ time of this manuscript submission, full results from OPERA I and II have not yet been published.

\section{Phase III study in PPMS}

Based on ocrelizumab's demonstrated efficacy depleting B-cells, which has been discussed earlier as a contributory factor in progressive MS, as well as rituximab's effect in subgroup analysis of PPMS patients, a Phase III trial has been conducted using ocrelizumab for primary progressive multiple sclerosis (ORATORIO). This multicenter, doubleblind, randomized, placebo-controlled trial enrolled PPMS patients (ages 18-55, baseline EDSS 3.0-6.5, elevated CSF IgG and OCB presence). Primary endpoint was time of onset to confirmed disability progression. Seven hundred and thirty two patients were randomized to receive ocrelizumab $600 \mathrm{mg}$ divided into two $300 \mathrm{mg}$ doses infused 2 weeks apart every 24 weeks; they were followed over a 120 -week treatment course period and were compared to placebo. The ocrelizumab group showed significant relative reduction in time to CDP $(24 \%$ and $25 \%$ for 12 -week and 24 -week, respectively). It addition, ocrelizumab also improved walking speed and radiographic disease measures such as T2 lesion burden progression and rate of brain atrophy. Of note, this study was designed to partially reflect the subgroup that had best results in the rituximab PPMS study. Also the proportion of subjects with presence of enhancing lesions at baseline was relatively high compared to prior PPMS trials (24\%). ${ }^{109}$ A subgroup analysis of subjects with and without enhancing lesions at baseline did not have sufficient power to make definitive conclusions. ${ }^{110}$ The results of ocrelizumab in PPMS are welcoming as this is the first example of efficacy from an anti-inflammatory DMT; however questions remain regarding the mechanism through which the medication is working. It is still unclear if the effect observed was purely through an effect on focal inflammation or a more specific mechanism on compartmentalized inflammation or another mechanism in PPMS. Study details of ocrelizumab in MS are presented in Table 1.

\section{Ocrelizumab safety}

Ocrelizumab infusions have been demonstrated to be welltolerated based on existing data from various MS and non-MS disease treatment trials. In a Phase I/II study of patients with refractory follicular lymphoma, ocrelizumab $200-700 \mathrm{mg} / \mathrm{m}^{2}$ infusions given 3 -weekly over 8 cycles were most commonly associated with IRR. Infectious events that most patients 
Table I Completed ocrelizumab in MS trials to date, with details on trial design and significant results

\begin{tabular}{|c|c|c|c|c|c|c|c|c|}
\hline Trial & Phase & Design & Population & $\begin{array}{l}\text { Sample } \\
\text { Size }\end{array}$ & $\begin{array}{l}\text { Ocrelizumab } \\
\text { Dosage }\end{array}$ & Duration & Outcomes & Adverse Events \\
\hline NCT006767/1577 & II & $\begin{array}{l}\text { Randomized, } \\
\text { double-blind, } \\
\text { placebo- } \\
\text { controlled }\end{array}$ & RRMS & 220 & $\begin{array}{l}600 \mathrm{mg} \text { (given } \\
\text { at } 300 \mathrm{mg} 2 \mathrm{~W} \\
\text { apart) first cycle, } \\
\text { then } 600 \mathrm{mg} \\
\text { second cycle } \\
2,000 \mathrm{mg} \text { (given } \\
\text { as } 1,000 \mathrm{mg} 2 \mathrm{~W} \\
\text { apart) first cycle, } \\
\text { then I,000 mg } \\
\text { second cycle }\end{array}$ & 48 weeks & $\begin{array}{l}\text { - } 80 \% \text { and } 73 \% \\
\text { reduction in ARR for } \\
600 \mathrm{mg} \text { and } 2,000 \mathrm{mg} \text {, } \\
\text { respectively } \\
89 \% \text { and } 96 \% \\
\text { reduction in \# of GEL } \\
\text { for } 600 \mathrm{mg} \text { and } 2,000 \\
\mathrm{mg}, \text { respectively }\end{array}$ & $\begin{array}{l}\text { - } 47 \%-66 \% \text { experienced } \\
\mathrm{AE} \\
\text { - } 2 \% \text { in } 600 \mathrm{mg} \text { group } \\
\text { experienced serious } \\
\mathrm{AE} \text { vs } 4 \%-6 \% \text { in } \\
2,000 \mathrm{mg} \text { group } \\
\text { - } 35 \% \text { and } 44 \% \\
\text { experienced IRR in } \\
600 \mathrm{mg} \text { and } 2,000 \mathrm{mg} \text {, } \\
\text { respectively } \\
\text { - No opportunistic } \\
\text { infections }\end{array}$ \\
\hline OPERA I/III08 & III & $\begin{array}{l}\text { Randomized, } \\
\text { double-blind, } \\
\text { IFN } \beta \text {-la } \\
\text { controlled }\end{array}$ & RRMS & $\begin{array}{l}821+ \\
835\end{array}$ & $\begin{array}{l}600 \mathrm{mg} \text { IV } \\
\text { Q24W }\end{array}$ & 96 weeks & $\begin{array}{l}\text { - } 46 \% \text { and } 47 \% \\
\text { reduction in ARR } \\
\text { - } 43 \% \text { and } 37 \% \text { risk } \\
\text { reduction to CDP at } \\
12 \text { and } 24 \text { weeks } \\
\text { - } 94 \% \text { and } 95 \% \\
\text { reduction in \# of GEL } \\
\text { - } 77 \% \text { and } 83 \% \\
\text { reduction in \# of new/ } \\
\text { enlarging } \mathrm{T} 2 \text { lesions }\end{array}$ & $\begin{array}{l}\text { - } 83.3 \% \text { experienced } \mathrm{AE} \\
\text { - } 6.9 \% \text { serious } \mathrm{AE} \\
\text { - } \mathrm{IRR} \text { most common } \mathrm{AE} \\
\text { ( } 34.3 \%) \\
\text { - } \mathrm{No} \mathrm{significant} \\
\text { difference to IFN }\end{array}$ \\
\hline ORATORIO 110 & III & $\begin{array}{l}\text { Randomized, } \\
\text { double-blind, } \\
\text { placebo- } \\
\text { controlled }\end{array}$ & PPMS & 732 & $\begin{array}{l}600 \mathrm{mg} \text { IV } \\
\text { Q24W (given } \\
\text { as } 300 \mathrm{mg} \\
2 \mathrm{~W} \text { apart) }\end{array}$ & 120 weeks & $\begin{array}{l}\text { - } 24 \% \text { and } 25 \% \text { risk } \\
\text { reduction of CDP } \\
\text { for } 12 \text { and } 24 \text { weeks, } \\
\text { respectively } \\
\text { - } 3.4 \% \text { decrease in } \mathrm{T} 2 \\
\text { lesion volume } \\
\text { - } 17.5 \% \text { reduced rate of } \\
\text { brain atrophy }\end{array}$ & $\begin{array}{l}\text { - } 20.4 \% \text { serious } \mathrm{AE} \\
\text { - } \mathrm{IRR} \text { most common } \mathrm{AE} \\
(39.9 \%) \\
\text { - No significant } \\
\text { difference to placebo }\end{array}$ \\
\hline
\end{tabular}

Abbreviations: AE, adverse event; IV, intravenous; ARR, annualized relapse rate; RRMS, relapsing-remitting multiple sclerosis; GEL, gadolinium-enhancing lesions; CDP, confirmed disability progression; PPMS, primary-progressive multiple sclerosis; Q24W, every 24 weeks; 2W, 2 weeks; IRR, infusion-related reaction.

experienced were mild infections that resolved without complications. One-third of patients experienced mild infections that were treated with antibiotics without complications. However, a few patients were found to have infusion-related lymphopenia, and there was one remotely related death due to pulmonary embolism in a patient with obliterate bronchiolitis 10 months after ocrelizumab infusion. ${ }^{102}$

More serious AEs were reported in a Phase I/II study of ocrelizumab in RA patients (ACTION trial) who were treated with escalating dosages ranging from 10 to $1,000 \mathrm{mg}$ given 2 weeks apart, and these AEs were observed over 72 weeks. Serious AEs were reported by $17.2 \%$ of ocrelizumab-treated patients including malignancies (abdominal wall mass, basal cell carcinoma, adenocarcinoma of lung, breast cancer, laryngeal cancer) and infections (sepsis, febrile neutropenia); there were also $2 \%$ of ocrelizumab-treated patients who reported nonserious infections such as URI and UTI. However, there was no clear AE patterns associated with varying dosages, and no significant differences in AEs compared to placebo. ${ }^{106}$
However, further ocrelizumab trials in RA were halted after the STAGE study (a Phase III randomized double-blind placebo-controlled trial assessing safety and efficacy of ocrelizumab in RA patients who were already on methotrexate) when results were independently analyzed as 3 patients who were on $1,000 \mathrm{mg}$ (500 mg infused 2 weeks apart) group had died ( 2 from pneumonia, 1 acute myocardial infarction), ${ }^{111}$ and so this was deemed too risky for RA population.

In MS patients from the Phase II RRMS trial, ${ }^{57}$ no differences in incidence of serious adverse events and serious infections were found between the two ocrelizumab groups vs placebo or IFN. Ocrelizumab-treated patients experienced more IRR. Patients who formed human anti-human antibodies (HAHA) were small in all groups, with 2 in the ocrelizumab $600 \mathrm{mg}$ group and 3 in placebo group by week 24. There also appears to be an inverse relationship between HAHA formation and ocrelizumab dosing. ${ }^{106}$ OPERA I/II and ORATORIO trials for PPMS reported similar incidence of infusion-related events similar to the ones reported in 
RRMS and other non-MS disease trials at the $600 \mathrm{mg}$ dose. The incidence of AEs was not significantly different across the different treatment arms.

It appears that ocrelizumab at the $600 \mathrm{mg}$ dose as used in MS trials does not have significant increase in serious AEs, outside of mild IRR. It is worth noting that there has been no significant increase in serious infectious events in ocrelizumab treated patients. However the long-term safety of the medication remains a potential concern, especially monitoring for the risk of PML. Ocrelizumab-induced B-cell depletion theoretically increases risk for PML, and thus longitudinal surveillance of ocrelizumab-treated patients needs to be performed.

\section{Other B-cell therapies}

In addition to ocrelizumab, other B-cell therapies are currently being investigated as potential treatments for PPMS. Completed trials and regulatory status are presented in Table 2.

Ofatumumab is a fully human anti-CD20 monoclonal antibody, like rituximab and ocrelizumab. Ofatumumab also binds to the CD20 molecule, but at a different epitope. Compared to rituximab, it has a slower dissociation rate and exhibits more potent CDC activity. ${ }^{75,112}$ It is currently approved for treatment-resistant CLL. ${ }^{113,114}$ In CLL patients who have received 300,700 , and $1,000 \mathrm{mg}$ of atumumab infusions, neutropenia was the most commonly observed serious AE, there was also an increase in serious AEs such as infection and bowel obstruction, which led to the death of 2 patients, although it was determined that it was not drug-induced. ${ }^{115}$ Safety and tolerability data in RA Phase I/ II studies showed that the most common AEs were mild to moderate IRR. Serious infections occurred in $1 \%-5 \%$ of patients, with one case of de novo hepatitis $\mathrm{B}$, which resulted in death. Malignancies occurred in $<2 \%$ of the patients, with benign malignancies being more common than serious malignancies (gingival cancer, lymphoma, ovarian cancer). ${ }^{116}$ In MS, a 24 week randomized, placebo-controlled, Phase II trial of ofatumumab (100, 300, and $700 \mathrm{mg})$ in 26 RRMS patients showed decreased new lesion development and total number of enhancing lesions by end of study, there is a dose-dependent response to relapse rate with the $700 \mathrm{mg}$ group free of relapse during the 24-week study period. B-cell depletion also was achieved in a dose-dependent manner. The most common adverse events experienced in this group were mild to moderate IRR, the serious adverse events reported were headache and anemia, which were determined unrelated to drug effect. ${ }^{117}$ In another study of ofatumumab in RRMS, subcutaneous injections of various ofatumumab dosages were studied in a larger population of 232 RRMS patients in a randomized, double-blind, parallel group, placebo-controlled trial (MIRROR). At the end of 12-weeks, there was a $65 \%$ reduction in new lesion formation on MRI. CD19+ cell depletion was achieved with all dosages. IRR were reported as in other studies. Higher dosing was associated with more serious AEs. ${ }^{118}$ In a follow-up study that observed the same MIRROR patients posttreatment, repletion of B-cells was observed in all groups at end of 48 weeks since receiving drug, the percentage of repletion was dose- and regimendependent, as the most frequent and highest dosing group had least percentage of patients with B-cell repletion. IRR remained the most common adverse event. ${ }^{119}$ No incidence of PML was observed in either study. Several ofatumumab studies in relapsing MS are currently under way.

Alemtuzumab is another humanized monoclonal antibody that affects B-cells. Its main mechanism of action is through binding of CD52, which is expressed on both $\mathrm{B}$ and T-cells, and acts via CDC and ADCC as well as induction of

Table 2 Currently available and investigational B-cell therapies for MS

\begin{tabular}{|c|c|c|c|c|}
\hline Drug & Antigen target, epitope & Trials completed & Trials ongoing & FDA approval \\
\hline \multirow[t]{2}{*}{ Ocrelizumab } & CD20, binds to large loop ${ }^{170} \mathrm{ANPS}^{173}$ core & Phase II in RRMS & & On fast-track evaluation \\
\hline & epitope, PI68 and PI70 assist in binding & Phase III in RRMS and PPMS & & for PPMS \\
\hline \multirow[t]{2}{*}{ Rituximab } & CD20, binds to large loop ${ }^{170} \mathrm{ANPS}^{173}$ core & Phase I and II in RRMS & Phase I in PPMS & \\
\hline & epitope, ${ }^{182} Y C Y S \mid{ }^{186}$ assists in binding & Phase II/III in PPMS & & \\
\hline \multirow[t]{2}{*}{ Ofatumumab } & CD20, binds to large loop FLKMESLNFIRAHTP & Phase II in RRMS & Phase III in RRMS & \\
\hline & core epitope and regions in small loop & & & \\
\hline Ublituximab & CD20 & & Phase II in RRMS & \\
\hline \multirow[t]{2}{*}{ Alemtuzumab } & CD52 & Phase II and III RRMS & & Approved for RRMS \\
\hline & & Phase II in SPMS and PPMS & & \\
\hline Atacicept & BAFF, APRIL & Phase II in RRMS & & \\
\hline Tabalumab & BAFF & Phase II RRMS & & \\
\hline Belimumab & BAFF & & & \\
\hline
\end{tabular}

Abbreviations: FDA, US Food and Drug Administration; PPMS, primary-progressive multiple sclerosis; RRMS, relapsing-remitting multiple sclerosis; SPMS, secondaryprogressive multiple sclerosis. 
apoptotic mechanisms. ${ }^{120-122}$ Treatment with alemtuzumab produced both B- and T-cell lymphopenia, with T-cell depletion lasting significantly longer than B-cell depletion. ${ }^{123,124}$ It has shown superior radiographic and clinical efficacy in RRMS compared to IFN $\beta-1 \mathrm{a}$ in both Phase II and Phase III (CARE MS I and CARE MS II) studies. ${ }^{123,125}$ It has been FDA approved to treat RRMS. As for progressive MS, the first experience with alemtuzumab was in a 1991 trial during which SPMS and PPMS patients were randomized to receive alemtuzumab infusions. In this study, the treatment group showed decrease in new lesion formation for at least 18 months. ${ }^{126}$ In a follow-up study involving 36 SPMS patients, alemtuzumab infusion showed similar efficacy in reducing new lesion formation; however, it did not prevent disability progression. ${ }^{127}$ The same group of progressive MS patients continued to decline clinically following 1 cycle of alemtuzumab infusion, with adverse event incidences as expected of untreated progressive MS. ${ }^{128}$

There is another group of novel humanized antibodies that indirectly influence B-cell population, and these have been found to be well-tolerated in various rheumatologic disease treatment trials. Among these types of therapies, agents currently/previously studied in MS include atacicept, tabalumab, and belimumab. Atacicept is a fully humanized protein that binds with high affinity to BAFF and APRIL - both of which are important regulators in the final stages of B-cell maturation. ${ }^{128}$ BAFF is expressed on B-cells membrane surface as well as existing as soluble factors in peripheral blood. ${ }^{129}$ Once bound, atacicept indirectly inhibits B-cell maturation and plasma cell formation through neutralizing the actions of BAFF and APRIL. In RA and SLE patients, atacicept was shown to be well-tolerated with only mild injection site reactions, and there is a significant (although not complete) reduction in total B-cell count that was dose dependent. ${ }^{130-132}$ Atacicept was studied in the ATAMS trial, a placebo-controlled, double-blind, 36-week, Phase II, multicenter trial that randomized 255 RRMS patients to receive atacicept or placebo. The response was less favorable despite similar immunologic data in immunoglobulin concentration and B-cell count reduction. The study was terminated early due to significantly increased ARR in the treatment group with no change in new lesion formation between the groups. ${ }^{133}$ It is unclear why atacicept, compared to other B-cell therapies, produced dramatically different results, it has been postulated that atacicept's effect on the late stages in B-cell maturation timeline as opposed to rituximab or ocrelizumab's effect on pre-B-cells and atacicept's incomplete depletion of peripheral B-cells may have accounted for the increase in clinical disease activity.
Similar to atacicept, tabalumab and belimumab are humanized monoclonal antibodies that also bind to BAFF. In Phase III trial of subcutaneous tabalumab injection in SLE, it was well-tolerated with no significant differences in serious AEs compared to placebo. However, there were incidences of opportunistic infections reported in the treatment group, including herpes zoster in $3.4 \%$ of patients, disseminated tuberculosis in $0.3 \%$, and cytomegalovirus in $0.3 \%$. Similar safety results were reported in a Phase III trial of tabalumab in RA. ${ }^{134}$ In RRMS, results from safety/efficacy study of tabalumab in a Phase II randomized, double-blind, parallel assignment trial has been completed but not reported. ${ }^{135}$

In patients with SLE, belimumab treatment resulted in sustained reduction of $\mathrm{CD} 20^{+} \mathrm{B}$-cell population as well as short-lived plasma cells in peripheral blood. No changes in T-cells or memory B-cells were seen. Adverse events were similar to that of placebo in terms of serious adverse infections, malignancies, and death; however, in the belimumab group there was a slight increase in depression rate. ${ }^{136}$ A few patients had severe hypersensitivity reaction after the first dose, which resolved with antihistamine treatment. ${ }^{137}$ Belimumab is currently FDA approved for treatment of SLE; however, its efficacy given the results of the atacicept trials in RRMS remains a question.

\section{Conclusion}

This review aimed to provide insight into B-cell directed therapy in the treatment of progressive MS. What has been traditionally thought of as an immune-mediated disease primarily driven by T-cells, has been proven to be even more complex with significant involvement of B-cells and their heterogenic roles in disease pathogenesis. Fortunately, with our increasing understanding of the intricate roles that B-cells play in MS, flexibility in MS therapy has also exponentially increased. There is an influx of immunomodulating biologics that have been specifically designed to target antigens crucial to B-cell maturation and signaling. As many of these existing B-cell therapies are already in use for a range of rheumatologic and oncologic diseases, the MS community benefits from this existing pool of safety data; such data can be utilized in designing various Phase I/II/ III trials in MS. Ocrelizumab is currently the most promising among its peers, with preliminary results from Phase III trials in RRMS and PPMS demonstrating encouraging clinical and radiographic outcomes. Its significance also rests on the fact that this is the first agent demonstrated to be safe and effective in treating PPMS, a subtype that has been more or less overlooked amid the crescendo in RRMS 
therapeutic developments. Nevertheless, questions regarding B-cell therapies still remain, such as their influences on regulatory $\mathrm{B}$-cells that possess anti-inflammatory functions and assist in disease recovery. For example, in certain EAE models, anti-CD20 treatment actually resulted in increased monocytic activity and reduced B-cell regulatory functions on T-cells and other antigen-presenting cells. ${ }^{138,139}$ It may be argued that agents that target only pathogenic B-cells may improve efficacy and safety compared to currently available agents. Second, there is probably a spectrum in terms of extent of pathogenic B-cell involvement in patients with MS; to identify these patients and stratify them based on immunologic profile, in addition to developing markers for therapy response, will assist in choosing and monitoring appropriate disease-specific therapies. As is the case with many of the existing MS therapeutic agents, there is also concern with regard to long-term safety beyond the scope of the clinical trials that will require meticulous postmarketing monitoring. Nevertheless, ocrelizumab, along with its multitude of B-cell oriented peers, thus far has provided fuel for the optimism in the future of MS therapy.

\section{Disclosure}

Dr Ontaneda has received consulting fees from Acorda Therapeutics, Biogen Idec, Genzyme, Genentech, Malinckrodt, and Novartis and research support from Genzyme and Novartis.

Dr Ontaneda is also supported by grant from The Clinical and Translational Science Collaborative KL2 program at Case Western University School of Medicine (grant number KL2 TR000440). The authors report no other conflicts of interest in this work.

\section{References}

1. Pearce JMS. Historical descriptions of multiple sclerosis. Eur Neurol. 2005;54(1):49-53.

2. The IFNB Multiple Sclerosis Study Group. Interferon beta-1b is effective in relapsing-remitting multiple sclerosis. I. Clinical results of a multicenter, randomized, double-blind, placebo-controlled trial. Neurology. 1993;43(4):655-661.

3. Jacobs LD, Cookfair DL, Rudick RA, et al. Intramuscular interferon beta-1a for disease progression in relapsing multiple sclerosis. Ann Neurol. 1996;39(3):285-294.

4. Kappos L, Group IMSS, Jacobs L, et al. Placebo-controlled multicentre randomised trial of interferon beta-1b in treatment of secondary progressive multiple sclerosis. Lancet. 1998;352(9139):1491-1497.

5. Kappos L, Weinshenker B, Pozzilli C, et al. Interferon beta-1b in secondary progressive MS: a combined analysis of the two trials. Neurology. 2004;63(10):1779-1787.

6. Johnson KP, Brooks BR, Cohen JA, et al. Copolymer 1 reduces relapse rate and improves disability in relapsing-remitting multiple sclerosis: results of a phase III multicenter, double-blind placebo-controlled trial. Neurology. 1995;45(7):1268-1276.

7. Johnson KP, Brooks BR, Ford CC, et al. Sustained clinical benefits of glatiramer acetate in relapsing multiple sclerosis patients observed for 6 years. Mult Scler. 2000;6(4):255-266.
8. Wolinsky JS, Narayana PA, O'Connor P, et al. Glatiramer acetate in primary progressive multiple sclerosis: results of a multinational, multicenter, double-blind, placebo-controlled trial. Ann Neurol. 2007; 61(1):14-24.

9. Hartung H-P, Gonsette R, König N, et al. Mitoxantrone in progressive multiple sclerosis: a placebo-controlled, double-blind, randomised, multicentre trial. Lancet. 2000;360(9350):2018-2025.

10. Polman CH, O'Connor PW, Havrdova E, et al. A randomized, placebocontrolled trial of natalizumab for relapsing multiple sclerosis. $\mathrm{NEngl}$ J Med. 2006;354(9):899-910.

11. Miller DH, Khan OA, Sheremata WA, et al. A controlled trial of natalizumab for relapsing multiple sclerosis. N Engl J Med. 2003;348(1): 15-23.

12. Rudick RA, Stuart WH, Calabresi PA, et al. Natalizumab plus interferon beta-1a for relapsing multiple sclerosis. $N$ Engl J Med. 2006;354(9):911-923.

13. Steiner D, Arnold DL, Freedman MS et al. Natalizumab versus placebo in patients with secondary progressive multiple sclerosis (SPMS): results from ASCEND, a multicenter, double-blind, placebo-controlled, randomized phase 3 clinical trial. Poster presented at 68th Annual Meeting of the American Academy of Neurology. April 14, 2016; Vancouver, BC.

14. Cohen JA, Barkhof F, Comi G, et al. Oral fingolimod or intramuscular interferon for relapsing multiple sclerosis. $N$ Engl J Med. 2010;362(5):402-415.

15. Kappos L, Radue E-W, O'Connor P, et al. A placebo-controlled trial of oral fingolimod in relapsing multiple sclerosis. $N$ Engl J Med. 2010;362(5):387-401.

16. Lublin F, Miller DH, Freedman MS, et al. Oral fingolimod in primary progressive multiple sclerosis (INFORMS): a phase 3, randomised, double-blind, placebo-controlled trial. Lancet. 2016;387(10023):1075-1084.

17. O'Connor P, Wolinsky JS, Confavreux C, et al. Randomized trial of oral teriflunomide for relapsing multiple sclerosis. $N$ Engl J Med. 2011;365(14):1293-1303.

18. Fox RJ, Miller DH, Phillips JT, et al. Placebo-controlled phase 3 study of oral BG-12 or glatiramer in multiple sclerosis. NEngl J Med. 2012;367(12):1087-1097.

19. Gold R, Kappos L, Arnold DL, et al. Placebo-controlled phase 3 study of oral BG-12 for relapsing multiple sclerosis. $N$ Engl J Med. 2012;367(12):1098-1107.

20. Naismith RT, Piccio L, Lyons JA, et al. Rituximab add-on therapy for breakthrough relapsing multiple sclerosis: a 52-week phase II trial. Neurology. 2010;74(23):1860-1867.

21. Bar-Or A, Calabresi PAJ, Arnold D, et al. Rituximab in relapsingremitting multiple sclerosis: A 72-week, open-label, phase I trial. Ann Neurol. 2008;63(3):395-400.

22. Hawker K, O'Connor P, Freedman MS, et al. Rituximab in patients with primary progressive multiple sclerosis: Results of a randomized double-blind placebo-controlled multicenter trial. Ann Neurol. 2009;66(4):460-471.

23. Coles AJ, Twyman CL, Arnold DL, et al. Alemtuzumab for patients with relapsing multiple sclerosis after disease-modifying therapy: a randomised controlled phase 3 trial. Lancet. 2012;380(9856):1829-1839.

24. Cohen JA, Coles AJ, Arnold DL, et al. Alemtuzumab versus interferon beta $1 \mathrm{a}$ as first-line treatment for patients with relapsing-remitting multiple sclerosis: a randomised controlled phase 3 trial. Lancet. 2012;380(9856):1819-1828.

25. Frohman EM, Racke MK, Raine CS. Multiple Sclerosis - The Plaque and Its Pathogenesis. N Engl J Med. 2006;354(9):942-955.

26. Kutzelnigg A, Lucchinetti CF, Stadelmann C, et al. Cortical demyelination and diffuse white matter injury in multiple sclerosis. Brain. 2005;128(11):2705-2712.

27. Peterson JW, Bö L, Mörk S, Chang A, Trapp BD. Transected neurites, apoptotic neurons, and reduced inflammation in cortical multiple sclerosis lesions. Ann Neurol. 2001;50(3):389-400.

28. Magliozzi R, Howell O, Vora A, et al. Meningeal B-cell follicles in secondary progressive multiple sclerosis associate with early onset of disease and severe cortical pathology. Brain. 2007;130(Pt 4):1089-1104. 
29. Serafini B, Rosicarelli B, Magliozzi R, Stigliano E, Aloisi F. Detection of ectopic B-cell follicles with germinal centers in the meninges of patients with secondary progressive multiple sclerosis. Brain Pathol. 2004;14(2):164-174.

30. Stern JNH, Yaari G, Vander Heiden JA, et al. B cells populating the multiple sclerosis brain mature in the draining cervical lymph nodes. Sci Transl Med. 2014;6(248):248ra107.

31. Franciotta D, Salvetti M, Lolli F, Serafini B, Aloisi F. B cells and multiple sclerosis. Lancet Neurol. 2008;7(9):852-858.

32. Colombo M, Dono M, Gazzola P, et al. Accumulation of clonally related B lymphocytes in the cerebrospinal fluid of multiple sclerosis patients. J Immunol. 2000;164(5):2782-2789.

33. Corcione A, Aloisi F, Serafini B, et al. B-cell differentiation in the CNS of patients with multiple sclerosis. Autoimmun Rev. 2005;4(8): 549-554.

34. Riedhammer C, Weissert R. Antigen presentation, autoantigens, and immune regulation in multiple sclerosis and other autoimmune diseases. Front Immunol. 2015;6:322.

35. Genain CP, Cannella B, Hauser SL, Raine CS. Identification of autoantibodies associated with myelin damage in multiple sclerosis. Nat Med. 1999;5(2):170-175.

36. Warren KG, Catz I. Relative frequency of autoantibodies to myelin basic protein and proteolipid protein in optic neuritis and multiple sclerosis cerebrospinal fluid. J Neurol Sci. 1994;121(1):66-73.

37. Blauth K, Soltys J, Matschulat A, et al. Antibodies produced by clonally expanded plasma cells in multiple sclerosis cerebrospinal fluid cause demyelination of spinal cord explants. Acta Neuropathol. 2015;130(6):765-781.

38. Srivastava R, Aslam M, Kalluri SR, et al. Potassium channel KIR4.1 as an immune target in multiple sclerosis. $N$ Engl $J$ Med. 2012;367(2):115-123.

39. Derfuss T, Parikh K, Velhin S, et al. Contactin-2/TAG-1-directed autoimmunity is identified in multiple sclerosis patients and mediates gray matter pathology in animals. Proc Natl Acad Sci U S A 2009;106(20):8302-8307.

40. Fillatreau S, Sweenie CH, McGeachy MJ, Gray D, Anderton SM. B cells regulate autoimmunity by provision of IL-10. Nat Immunol. 2002;3(10):944-950.

41. Wolf SD, Dittel BN, Hardardottir F, Janeway CA, Jr. Experimental autoimmune encephalomyelitis induction in genetically $\mathrm{B}$ cell-deficient mice. J Exp Med. 1996;184(6):2271-2278.

42. Yoshizaki A, Miyagaki T, DiLillo DJ, et al. Regulatory B cells control T-cell autoimmunity through IL-21-dependent cognate interactions. Nature. 2012;491(7423):264-268.

43. Cepok S, Jacobsen M, Schock S, et al. Patterns of cerebrospinal fluid pathology correlate with disease progression in multiple sclerosis. Brain. 2001;124(Pt 11):2169-2176.

44. Correale J, de los Milagros Bassani Molinas M. Oligoclonal bands and antibody responses in multiple sclerosis. $J$ Neurol. 2002;249(4): 375-389.

45. Dobson R, Ramagopalan S, Davis A, Giovannoni G. Cerebrospinal fluid oligoclonal bands in multiple sclerosis and clinically isolated syndromes: a meta-analysis of prevalence, prognosis and effect of latitude. J Neurol Neurosurg Psychiatry. 2013;84(8):909-914.

46. Jenkins MA, Cheng L, Ratnaike S. Multiple sclerosis: use of lightchain typing to assist diagnosis. Ann Clin Biochem. 2001;38(Pt 3): 235-241.

47. Senel M, Tumani H, Lauda F, et al. Cerebrospinal fluid immunoglobulin kappa light chain in clinically isolated syndrome and multiple sclerosis. PLoS One. 2014;9(4):e88680.

48. Joseph FG, Hirst CL, Pickersgill TP, Ben-Shlomo Y, Robertson NP, Scolding NJ. CSF oligoclonal band status informs prognosis in multiple sclerosis: a case control study of 100 patients. J Neurol Neurosurg Psychiatry. 2009;80(3):292-296.

49. Lundkvist M, Greiner E, Hillert J, Fogdell-Hahn A. Multiple sclerosis patients lacking oligoclonal bands in the cerebrospinal fluid are less likely to develop neutralizing antibodies against interferon beta. Mult Scler. 2010;16(7):796-800.
50. Avasarala JR, Cross AH, Trotter JL. Oligoclonal band number as a marker for prognosis in multiple sclerosis. Arch Neurol. 2001;58(12):2044-2045.

51. Fitzner B, Hecker M, Zettl UK. Molecular biomarkers in cerebrospinal fluid of multiple sclerosis patients. Autoimmun Rev. 2015;14(10):903-913.

52. Villar LM, Casanova B, Ouamara N, et al. Immunoglobulin M oligoclonal bands: biomarker of targetable inflammation in primary progressive multiple sclerosis. Ann Neurol. 2014;76(2):231-240.

53. Bosca I, Villar L, Coret F, et al. Response to interferon in multiple sclerosis is related to lipid-specific oligoclonal IgM bands. Mult Scler. 2010;16(7):810-815.

54. Bankoti J, Apeltsin L, Hauser SL, et al. In multiple sclerosis, oligoclonal bands connect to peripheral B-cell responses. Ann Neurol. 2014;75(2):266-276.

55. Cross AH, Stark JL, Lauber J, Ramsbottom MJ, Lyons J-A. Rituximab reduces $\mathrm{B}$ cells and $\mathrm{T}$ cells in cerebrospinal fluid of multiple sclerosis patients. J Neuroimmunol. 2006;180(1):63-70.

56. Hauser SL, Waubant E, Arnold DL, et al. B-cell depletion with rituximab in relapsing-remitting multiple sclerosis. $N$ Engl $J$ Med. 2008;358(7):676-688.

57. Kappos L, Li D, Calabresi PA, et al. Ocrelizumab in relapsing-remitting multiple sclerosis: a phase 2, randomised, placebo-controlled, multicentre trial. Lancet. 2011;378(9805):1779-1787.

58. Villar LM, García-Sánchez MI, Costa-Frossard L, et al. Immunological markers of optimal response to natalizumab in multiple sclerosis. Arch Neurol. 2012;69(2):191-197.

59. Harrer A, Tumani H, Niendorf S, et al. Cerebrospinal fluid parameters of B cell-related activity in patients with active disease during natalizumab therapy. Mult Scler. 2013;19(9):1209-1212.

60. Shi K, Hayashida K, Kaneko M, et al. Lymphoid chemokine B cellattracting chemokine-1 (CXCL13) is expressed in germinal center of ectopic lymphoid follicles within the synovium of chronic arthritis patients. J Immunol. 2001;166(1):650-655.

61. Randen I, Mellbye OJ, Førre O, Natvig JB. The identification of germinal centres and follicular dendritic cell networks in rheumatoid synovial tissue. Scand J Immunol. 1995;41(5):481-486.

62. Amft N, Curnow SJ, Scheel-Toellner D, et al. Ectopic expression of the B cell-attracting chemokine BCA-1 (CXCL13) on endothelial cells and within lymphoid follicles contributes to the establishment of germinal center-like structures in Sjogren's syndrome. Arthritis Rheum. 2001;44(11):2633-2641.

63. Mosnier JF, Degott C, Marcellin P, Hénin D, Erlinger S, Benhamou JP. The intraportal lymphoid nodule and its environment in chronic active hepatitis C: an immunohistochemical study. Hepatology. 1993;17(3):366-371.

64. Mahad DH, Trapp BD, Lassmann H. Pathological mechanisms in progressive multiple sclerosis. Lancet Neurol. 2015;14(2):183-193.

65. Howell OW, Reeves CA, Nicholas R, et al. Meningeal inflammation is widespread and linked to cortical pathology in multiple sclerosis. Brain. 2011;134(Pt 9):2755-2771.

66. Haugen M, Frederiksen JL, Degn M. B cell follicle-like structures in multiple sclerosis-with focus on the role of B cell activating factor. J Neuroimmunol. 2014;273(1-2):1-7.

67. Absinta M, Vuolo L, Rao A, et al. Gadolinium-based MRI characterization of leptomeningeal inflammation in multiple sclerosis. Neurology. 2015;85(1):18-28.

68. Choi SR, Howell OW, Carassiti D, et al. Meningeal inflammation plays a role in the pathology of primary progressive multiple sclerosis. Brain. 2012;135(10):2925-2937.

69. Li R, Rezk A, Miyazaki Y, et al. Proinflammatory GM-CSF-producing B cells in multiple sclerosis and B cell depletion therapy. Sci Transl Med. 2015;7(310):310ra166.

70. Merrill JE, Wåhlin B, Sidén A, Perlmann P. Elevated direct and IgM enhanced ADCC activity in multiple sclerosis patients. J Immunol. 1982;128(4):1728-1735.

71. Frick E, Stickl H. Specificity of antibody-dependent lymphocyte cytotoxicity against cerebral tissue constituents in multiple sclerosis. Acta Neurol Scand. 1982;65(1):30-37. 
72. Robak T, Robak E. New anti-CD20 monoclonal antibodies for the treatment of B-cell lymphoid malignancies. BioDrugs. 2011;25(1):13-25.

73. Ivanov A, Beers SA, Walshe CA, et al. Monoclonal antibodies directed to CD20 and HLA-DR can elicit homotypic adhesion followed by lysosome-mediated cell death in human lymphoma and leukemia cells. J Clin Invest. 2009;119(8):2143-2159.

74. Polyak MJ, Deans JP. Alanine-170 and proline-172 are critical determinants for extracellular CD20 epitopes; heterogeneity in the fine specificity of CD20 monoclonal antibodies is defined by additional requirements imposed by both amino acid sequence and quaternary structure. Blood. 2002;99(9):3256-3262.

75. Teeling JL, Mackus WJM, Wiegman LJJM, et al. The biological activity of human CD20 monoclonal antibodies is linked to unique epitopes on CD20. J Immunol. 2006;177(1):362-371.

76. Binder M, Otto F, Mertelsmann R, Veelken H, Trepel M. The epitope recognized by rituximab. Blood. 2006;108(6):1975-1978.

77. Du J, Wang H, Zhong C, et al. Crystal structure of chimeric antibody $\mathrm{C} 2 \mathrm{H} 7 \mathrm{Fab}$ in complex with a CD20 peptide. Mol Immunol. 2008;45(10):2861-2868.

78. de Romeuf C, Dutertre C-A, Le Garff-Tavernier M, et al. Chronic lymphocytic leukaemia cells are efficiently killed by an anti-CD20 monoclonal antibody selected for improved engagement of Fc $\gamma$ RIIIA/ CD16. Br J Haematol. 2008;140(6):635-643.

79. O'Conner OA, Schreeder MT, Deng C, et al. Ublituximab (tg-1101), a novel anti-cd 20 monoclonal antibody for rituximab relapsed/refractory b-cell malignancies. In: 18th Congress of the European Hematology Association. Stockholm, Sweden. 2014.

80. Clynes RA, Towers TL, Presta LG, Ravetch J V. Inhibitory Fc receptors modulate in vivo cytotoxicity against tumor targets. Nat Med. 2000;6(4):443-446.

81. Palanichamy A, Jahn S, Nickles D, et al. Rituximab efficiently depletes increased CD20-expressing T cells in multiple sclerosis patients. J Immunol. 2014;193(2):580-586.

82. Piccio L, Naismith RT, Trinkaus K, et al. Changes in B- and T-lymphocyte and chemokine levels with rituximab treatment in multiple sclerosis. Arch Neurol. 2010;67(6):707-714.

83. Lee W-J, Lee S-T, Byun J-I, et al. Rituximab treatment for autoimmune limbic encephalitis in an institutional cohort. Neurology. 2016;86(18):1683-1691.

84. Toyoshima D, Morisada N, Takami Y, et al. Rituximab treatment for relapsed opsoclonus-myoclonus syndrome. Brain Dev. 2016;38(3):346-349.

85. Iorio R, Damato V, Alboini PE, Evoli A. Efficacy and safety of rituximab for myasthenia gravis: a systematic review and meta-analysis. J Neurol. 2015;262(5):1115-1119.

86. Collongues N, de Seze J. An update on the evidence for the efficacy and safety of rituximab in the management of neuromyelitis optica. Ther Adv Neurol Disord. 2016;9(3):180-188.

87. Radaelli M, Moiola L, Sangalli F, et al. Neuromyelitis optica spectrum disorders: long-term safety and efficacy of rituximab in Caucasian patients. Mult Scler. 2016;22(4):511-519.

88. Bourdette D. Rituximab for treating multiple sclerosis: Off-label but on target. Neurology. 2016;87(20):2070-2071.

89. Salzer J, Svenningsson R, Alping P, et al. Rituximab in multiple sclerosis: A retrospective observational study on safety and efficacy. Neurology. 2016;87(20):2074-2081.

90. Alping P, Frisell T, Novakova L, et al. Rituximab versus fingolimod after natalizumab in multiple sclerosis patients. Ann Neurol. 2016;79(6):950-958.

91. Anderson KC, Bates MP, Slaughenhoupt BL, Pinkus GS, Schlossman SF, Nadler LM. Expression of human B cell-associated antigens on leukemias and lymphomas: a model of human B cell differentiation. Blood. 1984;63(6):1424-1433.

92. Carson KR, Evens AM, Richey EA, et al. Progressive multifocal leukoencephalopathy after rituximab therapy in HIV-negative patients: a report of 57 cases from the Research on Adverse Drug Events and Reports project. Blood. 2009;113(20):4834-4840.
93. Major EO. Progressive Multifocal Leukoencephalopathy in Patients on Immunomodulatory Therapies. Annu Rev Med. 2010;61(1): $35-47$.

94. Clifford DB, Ances B, Costello C, et al. Rituximab-associated progressive multifocal leukoencephalopathy in rheumatoid arthritis. Arch Neurol. 2011;68(9):1156-1164.

95. Cree BAC, Lamb S, Morgan K, Chen A, Waubant E, Genain C. An open label study of the effects of rituximab in neuromyelitis optica. Neurology. 2005;64(7):1270-1272.

96. Kim S-H, Huh S-Y, Lee SJ, et al. A 5-Year Follow-up of Rituximab Treatment in Patients With Neuromyelitis Optica Spectrum Disorder. JAMA Neurol. 2013;70(9):1110.

97. Pellkofer HL, Krumbholz M, Berthele A, et al. Long-term followup of patients with neuromyelitis optica after repeated therapy with rituximab. Neurology. 2011;76(15):1310-1315.

98. Bedi GS, Brown AD, Delgado SR, Usmani N, Lam BL, Sheremata WA. Impact of rituximab on relapse rate and disability in neuromyelitis optica. Mult Scler. 2011;17(10):1225-1230.

99. Kim S-H, Jeong IH, Hyun J-W, et al. Treatment Outcomes With Rituximab in 100 Patients With Neuromyelitis Optica: Influence of FCGR3A Polymorphisms on the Therapeutic Response to Rituximab. JAMA Neurol. 2015;72(9):989-995.

100. Stashenko P, Nadler LM, Hardy R, Schlossman SF. Characterization of a human B lymphocyte-specific antigen. J Immunol. 1980;125(4):1678-1685.

101. Stashenko P, Nadler LM, Hardy R, Schlossman SF. Expression of cell surface markers after human B lymphocyte activation. Proc Natl Acad Sci U S A. 1981;78(6):3848-3852.

102. Morschhauser F, Marlton P, Vitolo U, et al. Results of a phase I/II study of ocrelizumab, a fully humanized anti-CD20 $\mathrm{mAb}$, in patients with relapsed/ refractory follicular lymphoma. Ann Oncol. 2010;21(9):1870-1876.

103. Vugmeyster Y, Beyer J, Howell K, et al. Depletion of B cells by a humanized anti-CD20 antibody PRO70769 in Macaca fascicularis. J Immunother. 2005;28(3):212-219.

104. Buttmann M. Treating multiple sclerosis with monoclonal antibodies: a 2010 update. Expert Rev Neurother. 2010;10(5):791-809.

105. Gasperini C, Haggiag S, Ruggieri S. Drugs in clinical development for multiple sclerosis: focusing on anti-CD20 antibodies. Expert Opin Investig Drugs. 2013;22(10):1243-1253.

106. Genovese MC, Kaine JL, Lowenstein MB, et al. Ocrelizumab, a humanized anti-CD20 monoclonal antibody, in the treatment of patients with rheumatoid arthritis: A phase I/II randomized, blinded, placebo-controlled, dose-ranging study. Arthritis Rheum. 2008;58(9):2652-2661.

107. Kausar F, Mustafa K, Sweis G, et al. Ocrelizumab: a step forward in the evolution of B-cell therapy. Expert Opin Biol Ther. 2009;9(7):889-895.

108. Hauser SL, Comi GC, Hartung H-P, et al. Efficacy and safety of ocrelizumab in relapsing multiple sclerosis - results of the interferon-beta1a-controlled, double-blind, Phase III OPERA I and II studies. Poster presented at: $31^{\text {st }}$ Congress of the European Committee for Treatment and Research in Multiple Sclerosis; Sep 23, 2015; Barcelona, Spain.

109. Wolinsky J, Arnold DL, Bar-Or A, et al. Efficacy of ocrelizumab in patients with PPMS with and without T1 gadolinium-enhancing lesions at baseline in a phase iii, placebo-controlled trial. Poster presented at Americas Committee for Treatment and Research in Multiple Sclerosis. Jun 3, 2016; National Harbor, MD.

110. Montalban X, Hemmer B, Rammohan K et al. Efficacy and Safety of Ocrelizumab in Primary Progressive Multiple Sclerosis: Results of the Phase III Double-Blind, Placebo-Controlled ORATORIO Study. Neurology. 2016;86(16 Suppl):S49.001.

111. Rigby W, Tony H-P, Oelke K, et al. Safety and efficacy of ocrelizumab in patients with rheumatoid arthritis and an inadequate response to methotrexate: Results of a forty-eight-week randomized, double-blind, placebo-controlled, parallel-group phase III trial. Arthritis Rheum. 2012;64(2):350-359.

112. Teeling JL, French RR, Cragg MS, et al. Characterization of new human CD20 monoclonal antibodies with potent cytolytic activity against non-Hodgkin lymphomas. Blood. 2004;104(6):1793-1800. 
113. Hillmen P, Robak T, Janssens A, et al. Chlorambucil plus ofatumumab versus chlorambucil alone in previously untreated patients with chronic lymphocytic leukaemia (COMPLEMENT 1): a randomised, multicentre, open-label phase 3 trial. Lancet. 2015;385(9980): $1873-1883$

114. Österborg A, Udvardy M, Zaritskey A, et al. Phase III, randomized study of ofatumumab versus physicians' choice of therapy and standard versus extended-length ofatumumab in patients with bulky fludarabine-refractory chronic lymphocytic leukemia. Leuk Lymphoma. 2016;57(9):2037-2046.

115. van Oers MHJ, Kuliczkowski K, Smolej L, et al. Ofatumumab maintenance versus observation in relapsed chronic lymphocytic leukaemia (PROLONG): an open-label, multicentre, randomised phase 3 study. Lancet Oncol. 2015;16(13):1370-1379.

116. Quattrocchi E, Østergaard M, Taylor PC, et al. Safety of repeated open-label treatment courses of intravenous ofatumumab, a human anti-CD20 monoclonal antibody, in rheumatoid arthritis: results from three clinical trials. PLoS One. 2016;11(6):e0157961.

117. Sorensen PS, Lisby S, Grove R, et al. Safety and efficacy of ofatumumab in relapsing-remitting multiple sclerosis: a phase 2 study. Neurology. 2014;82(7):573-581.

118. Bar-Or A, Grove R, Austin D, et al. The MIRROR study: a randomized, double-blind, placebo-controlled, parallel-group, dose-ranging study to investigate the safety and MRI efficacy of subcutaneous ofatumumab in subjects with relapsing-remitting multiple sclerosis (RRMS). Neurology. 2014;82(10):S23.006.

119. Sørensen PS. Follow-up data from the Mirror study: a dose-ranging study of subcutaneous ofatumumab in subjects with relapsing-remitting multiple sclerosis. Poster presented at: 2014 Joint ACTRIMSECTRIMS Meeting; Sep 10-13; 2014; Boston, MA.

120. Zent CS, Secreto CR, LaPlant BR, et al. Direct and complement dependent cytotoxicity in CLL cells from patients with high-risk early-intermediate stage chronic lymphocytic leukemia (CLL) treated with alemtuzumab and rituximab. Leuk Res. 2008;32(12): 1849-1856.

121. Golay J, Manganini M, Rambaldi A, Introna M. Effect of alemtuzumab on neoplastic B cells. Haematologica. 2004;89(12):1476-1483.

122. Smolewski P, Szmigielska-Kaplon A, Cebula B, et al. Proapoptotic activity of alemtuzumab alone and in combination with rituximab or purine nucleoside analogues in chronic lymphocytic leukemia cells. Leuk Lymphoma. 2005;46(1):87-100.

123. The CAMMS223 Trial Investigators. Alemtuzumab vs. Interferon Beta-1a in Early Multiple Sclerosis. N Engl J Med. 2008;359(17): 1786-1801.

124. Hill-Cawthorne GA, Button T, Tuohy O, et al. Long term lymphocyte reconstitution after alemtuzumab treatment of multiple sclerosis. J Neurol Neurosurg Psychiatry. 2012;83(3):298-304.

125. Arnold DL, Fisher E, Brinar V V, et al. Superior MRI outcomes with alemtuzumab compared with subcutaneous interferon $\beta$-1a in MS Neurology. 2016;87(14):1464-1472.
126. Coles AJ, Wing MG, Molyneux P, et al. Monoclonal antibody treatment exposes three mechanisms underlying the clinical course of multiple sclerosis. Ann Neurol. 1999;46(3):296-304.

127. Coles AJ, Cox A, Page E, et al. The window of therapeutic opportunity in multiple sclerosis. J Neurol. 2006;253(1):98-108.

128. Davidson A. Targeting BAFF in autoimmunity. Curr Opin Immunol. 2010;22(6):732-739.

129. Schneider P, MacKay F, Steiner V, et al. BAFF, a novel ligand of the tumor necrosis factor family, stimulates B Cell growth. J Exp Med. 1999;189(11):1747-1756.

130. Tak PP, Thurlings RM, Rossier C, et al. Atacicept in patients with rheumatoid arthritis: results of a multicenter, phase $\mathrm{Ib}$, double-blind, placebo-controlled, dose-escalating, single- and repeated-dose study. Arthritis Rheum. 2008;58(1):61-72.

131. Dall'Era M, Chakravarty E, Wallace D, et al. Reduced B lymphocyte and immunoglobulin levels after atacicept treatment in patients with systemic lupus erythematosus: results of a multicenter, phase Ib, double-blind, placebo-controlled, dose-escalating trial. Arthritis Rheum. 2007;56(12):4142-4150.

132. Pena-Rossi C, Nasonov E, Stanislav M, et al. An exploratory doseescalating study investigating the safety, tolerability, pharmacokinetics and pharmacodynamics of intravenous atacicept in patients with systemic lupus erythematosus. Lupus. 2009;18(6):547-555.

133. Kappos L, Hartung H-P, Freedman MS, et al. Atacicept in multiple sclerosis (ATAMS): a randomised, placebo-controlled, double-blind, phase 2 trial. Lancet Neurol. 2008;13(4):353-363.

134. Schiff M, Combe B, Dörner T, et al. Efficacy and safety of tabalumab, an anti-BAFF monoclonal antibody, in patients with moderate-tosevere rheumatoid arthritis and inadequate response to TNF inhibitors: results of a randomised, double-blind, placebo-controlled, phase 3 study. RMD Open. 2015;1(1):e000037.

135. Eli Lilly and Company. Multiple subcutaneous doses of LY2127399, an anti-BAFF human antibody, in subjects with relapsing-remitting multiple sclerosis. Available from: https://clinicaltrials.gov/ct2/show/ NCT00882999. NLM Identifier: NCT00882999. Accessed August 17, 2016.

136. Furie R, Petri M, Zamani O, et al. A phase III, randomized, placebocontrolled study of belimumab, a monoclonal antibody that inhibits $\mathrm{B}$ lymphocyte stimulator, in patients with systemic lupus erythematosus. Arthritis Rheum. 2011;63(12):3918-3930.

137. Navarra S V, Guzmán RM, Gallacher AE, et al. Efficacy and safety of belimumab in patients with active systemic lupus erythematosus: a randomised, placebo-controlled, phase 3 trial. Lancet. 2011;377(9767):721-731.

138. Lehmann-Horn K, Schleich E, Hertzenberg D, et al. Anti-CD20 B-cell depletion enhances monocyte reactivity in neuroimmunological disorders. J Neuroinflammation. 2011;8(1):146.

139. Weber MS, Prod'homme T, Patarroyo JC, et al. B-cell activation influences T-cell polarization and outcome of anti-CD20 B-cell depletion in central nervous system autoimmunity. Ann Neurol. 2010;68(3):369-383.
Degenerative Neurological and Neuromuscular Disease

\section{Publish your work in this journal}

Degenerative Neurological and Neuromuscular Disease is an international, peer-reviewed, open access journal focusing on research into degenerative neurological and neuromuscular disease, identification of therapeutic targets and the optimal use of preventative and integrated treatment interventions to achieve improved outcomes, enhanced

\section{Dovepress}

survival and quality of life for the patient. The manuscript management system is completely online and includes a very quick and fair peer-review system. Visit http://www.dovepress.com/testimonials.php to read real quotes from published authors. 